quickly? On the one hand, on becoming adults it will be easier for them to study at a Norwegian university and to be integrated into the Norwegian labour market. On the other hand, one could say that by being so speedily transformed into Norwegians, they will become 'victims' or objects of accelerated assimilation. If these youngsters manage to keep a fraction of their Russian identity, they would be able to transfer some of their identity to the next generation, part of their language, a number of traditions, knowledge of and interest in Russia in general. Thereby, they will be able, not only through active links between Norway and future immigrants from Russia, but also to increase the understanding of Russia and Russian culture in Norway (Kuortti and Nyman 2007).

\section{References}

Alba, R., and V. Nee. 2003. Remarking the American mainstream: assimilation and contemporary immigration. Cambridge, MA: Harvard University Press.

Baumann, G. 1999. The multicultural riddle: rethinking national, ethic, and religious identities. New York: Routledge.

Bell, D.S., M. Pennington, and J. Bara. 2009. Comparative politics: explaining democratic systems. Los Angeles: Sage.

Bhabha, H.K. 1990. Nation and narration. London: Routledge.

Gordon, M.M. 1964. Assimilation in American life: the role of race, religion, and national origins. New York: Oxford University Press.
Holton, R.J. 1998. Globalisation and the nation-state. Basingstoke: Macmillan.

Kalra, V.S., R. Kaur, and J. Hutnyk. 2005. Diaspora and hybridity. London, Thousand Oaks, CA: SAGE Publications.

Kelly, P.J. 2002. Multiculturalism reconsidered: culture and equality and its critics. Cambridge: Polity Press.

Kumar, K. 2005. From post-industrial society to post-modern society: new theories of the contemporary world. Malden, MA: Blackwell.

Kuortti, J., and J. Nyman. 2007. Reconstructing hybridity: postcolonial studies in transition. Amsterdam: Rodopi.

Leont'ev, A.N. 1983. Izbrannye psikhologicheskie trudy [Collected psychological works]. Vol.2. Moscow: Izdatel'stvo Pedagogica.

Modood, T. 2007. Multiculturalism: a civil idea. Cambridge: Polity. Morawska, E., and C. Joppke. 2003. Towards assimilation and citizenship: immigrants in liberal nation-states. Basingstoke: Palgrave Macmillan.

Penn, R., and P. Lambert. 2009. Children of international migrants in Europe. Comparative perspectives. Palgrave: Macmillan.

Rogova, A. 2008. From rejection to re-embracement. Language and identity of the Russian speaking minority in Kirkenes. Kirkenes: Barents Institute.

Statistisk Sentralbyra i Norge. 2000-2009. URL: http://ssb.no

Tevlina, V.V. 2009. Norvezhsko-rossiiskie vzaimootnoshenia $v$ khode sotsial'nykh reform (konets 20 - nachalo 21 veka) [Norwegian-Russian relationships during the social reforms (the end of the 20th and the beginning of the 21 century)]. Biulleten' Pomorskogo universiteta 1: 54-67.

Vygotskii, L.S. 1982. Sobranie sochineniy [Collected works]. Vol.2. Moscow: Izdatel'stvo Pedagogica.

\title{
Variations of ethnic boundary significance in north Norway Trond Thuen
}

Department of Archaeology and Social Anthropology, University of Troms $\emptyset$, N-9037 Troms $\varnothing$, Norway (trond.thuen@uit.no)

ABSTRACT. In coastal north Norway the Saami people have lived in a close relationship with Norwegians or Norse people for a thousand years or more. This relationship has been articulated in various ways over the centuries, and this article argues that in parts of the region it took a rather intimate form based on the shared exploitation of the dominant marine and terrestrial niches, a common class position as tenant farmers, a varying practice of inter-ethnic marital relations and the effects of a bilateral kinship system. Various forms of inter-ethnic contact and exchange may thus have served to reduce the relevance of ethnic difference in daily life, as suggested by Barth's argument about the integrative effect of transactions, but contrary to his argument about the transactional reinforcement of ethnic boundaries. Contrary to the intention, governmental assimilatory efforts served to reproduce the boundary as the basis for a ranked society and left coastal Saami individuals in some confusion as to how to define themselves, often opting for a mixed category of Norwegian and Saami, labelled 'Northerner'. Ethno-political emancipation in recent years has tended to put pressure on this identity construction and promoted a dichotomised identity as either Saami or Norwegian.

\section{Introduction: fuzzy boundaries?}

It is a salient aspect of present-day globalisation that the identification of 'self' with a specific ethnic category, and the corresponding ascription of a contrasting categor- ical definition to 'the other', have become a subject of contested discourse. This discourse seems to have two distinct aspects: on one hand it is a question of how individuals relate to each other through interaction for 
all sorts of everyday purposes and to what extent selfpresentation of identity can be variously moulded, and on the other hand ethnic categorisations are increasingly being objectified as an issue in itself. People everywhere are confronted with the task of relating adequately to others, not just as new acquaintances, but also when these others until recently used to be defined according to well-known, pre-established categorical boundaries. And parallel to this disorder of interpersonal behaviour prescriptions is a debate on the politically correct way of categorisation as such. This is basically a question of where to draw boundaries, that is who should be included and who should be excluded in the 'us' and 'them' categories, or, in other words, how fluid and flexible do we accept the content to be of what the boundaries comprise concerning behaviour patterns, cultural symbols, speech, etc.

This article addresses changing patterns of identity definitions and -presentations in the northernmost region of coastal Norway, that is the counties of Troms and western Finnmark. One should remember, however, that there are important variations in ethnic articulation also within this region.

I do not pretend to rewrite history, nor do I present any alternative to existing tenets of ethnicity theory. My purpose is rather to illustrate, through a generalised presentation of some presumably basic aspects of the Saami-Norwegian encounter, how interpersonal conceptualisations of similarity and difference correlate not only to ethnicity but also, and presumably more fundamentally, to class, and how they in turn affect personal articulations of identity. My presentation is based on various readings of historical material and recent contributions to the study of ethnicity in north Norway, as well as my own fieldwork experiences from coastal communities with a 'mixed' population.

In an analytical sense my aim is to investigate critically the relationship between 'ethnic boundaries' as constituted by avoidance or a very limited shared field of interaction, on the one hand, and on the other the integrative effect on evaluations, forms of knowledge and social cohesion that interaction propelled by local encounters and cohabitation of people with different ethnic ascriptions seems to have engendered. Here I argue that some of Barth's statements in his early writings (1966, 1969) may seem to contradict each other.

\section{Ethnicity and class in coastal north Norway}

This region has a special history of sociocultural contact between people of Saami, Norwegian, and, in later centuries, Kven ancestry ${ }^{1}$, which goes back more than a millennium and is somewhat atypical compared to colonial histories that elsewhere characterise indigeneity ${ }^{2}$. This atypical colonial past can only be properly explained when, aside from the obvious ethnic contrast, the class dimension is integrated in the analysis. It is my argument that we will achieve a more adequate understanding of inter-ethnic processes and identity formations if we apply a longitudinal, historical approach to our object of analysis, that is the role that ethnicity plays in the social organisation of everyday life. This role is determined by the interplay of ecological conditions dictating the basic prerequisites for survival, political contexts that determine opportunities for subordination as well as emancipation, and economic conditions that decide one's access to natural resources and how these can be transformed into values to be distributed systematically to the population. We will then see that the ethnic encounter over the centuries also engendered class boundaries that did not coincide with ethnic categories, and which created, to some extent, a complex of shared conditions and opportunities amongst people inhabiting large parts of coastal north Norway and being clearly distinct from, on one side the Norwegian élite, and on the other, the reindeerbreeding Saami of the interior of the region. In this broad historical perspective it may then be argued that in a very basic sense the experience of belonging to the same class of peasants/fishers weakened the significance of the ethnic border. And added to this shared social position in society, people on the coast also shared the same ecological environment and the techniques and types of knowledge that survival in this landscape demanded.

The question of what significance ethnic selfascription and ascription by others actually has in everyday social interaction today is influenced heavily by an extensive discourse fuelled by the continuous politicisation of ethnicity. This discourse also invites a historical perspective, namely the context of a more than hundred years period of assimilation and nation-building policies instigated by the 19th century governments of Norway after its independence from Denmark (1814) and during its search for national autonomy from Sweden (achieved in 1905) and its efforts to consolidate national unity, mainly through the school system. After independence and through the 20th century until the present day a primary task of the state has been to promote economic progress and welfare through various modernisation measures, notably through the class levelling ideology of Labour governments. The policy of ethnic assimilation meant integration within the wider Norwegian national society and reinforced the local and regional ethnic boundary by making identity a political as well as a personal concern (Eidheim 1971; Minde 2003).

It is against this background that we should understand why the question of what it means to be a 'Norwegian', a 'Northerner', a 'Saami' or a 'Kven' increasingly has become contested as the Saami have achieved official recognition of their status as an indigenous people through a process of emancipation over the last 30-40 years. As various contributors to the academic discourse on issues related to identities and ethnic categorisation in north Norway have emphasised, the conventional dichotomisation between Saami and Norwegian (and to some extent Kven) is felt to be a straitjacket for many people (Kramvig 2005; Gaski 2008; Olsen 2008; Hovland 1996; 
Paine 2003; Storaas 2007; Thuen 2002, 2007). It is argued that the categorical prescriptions in the regional and national political discourses on ethnically related issues, typically offered in the form of an allegedly unambiguous 'either-or' dichotomy between Saami and Norwegians, contradicts the individual and local experiences characterising the life worlds of coastal populations. In other words, what we have here is a particularly conspicuous case of contested borders and identities. Consequently, the issue demands some further analytical clarification. This is not just a question of academic or political categorisations being wrongly conceived. Both clear-cut and hybrid identity categories exist, and not only at different points in time and space. Evidently they co-exist and even may be ascribed to interchangeably by the same person. In some cases it is the social situation that defines the relevant presentation of self and not, as argued in Barth's (1969) groundbreaking contribution to ethnicity theory, that ethnic categories are dominant in interaction and prescribe the relevant definition of the social situation and the forms of interaction that are possible within this framing.

The way to understand what ethnicity is about in this region in each particular case is to look closely at conceptualisations of personhood articulated in interpersonal micro-level contexts. Over the centuries of inter-ethnic contacts in the north, ethnic boundaries have been confirmed, negotiated and rejected. To understand the dynamics of boundary processes we thus need to understand how they are fuelled partly by locally produced experience, partly by state orchestrated schemes of control through preconceived categorical definitions of its subjects. It is a well-established fact that states demand clear-cut definitions of its citizenry for all sorts of control purposes (Scott 1998). The creation of a shared nationhood, as it pervaded governmental ambitions in Norway during the 19th and well into the 20th century, was focused on integrating minority ethnicities in the majority at the same time as and partly as a means to promoting modernisation, class levelling and economic progress. To deserve being a member of the national collective citizens should have a recognisable common language, belong to the same religious belief system, and articulate a certain level of national loyalty.

\section{Social interaction - reducing or confirming categorical boundaries?}

However, the ethnic boundary did not and does not have the same types of significance at the national level as it has at the local level. In daily life it is articulated along with a range of other status positions defining the local person and determining its capacities for taking part in social interchange. Amongst these bonds kinship, neighbourhood and class should be considered the salient ones. The focus on ethnicity may be argued to have attracted too much attention in the anthropological analysis of structural dimensions in the north of Norway, to the effect of rendering it essential and to the neglect of other aspects of social organisation.

What I intend to discuss here is the interplay of social forces engendering the invigoration as well as the obliteration of the ethnic boundary between 'Saami' and 'Norwegians' (in quotation marks to emphasise that the labels are differently constructed and varying situationally). 'Fuzzy boundaries' may seem a contradiction of terms, but it is a way to question the notion that ethnic identity is ipso facto 'imperative and cannot be temporarily put aside' (Barth 1969: 17). For the purpose of this discussion it is of interest to go back to Barth and his pair of most groundbreaking contributions to anthropological theory, Models of social organisation (1966) and the 'Introduction' to Ethnic groups and boundaries (1969). Arguments from both texts have been compared and discussed before, notably by Paine (1974), but still seem of relevance in the context of the present discussion. It clearly also needs to be added that ethnicity theory has been refined in various ways since Barth's original contribution, not least by himself in his contribution (Barth 1994) to the edited volume The anthropology of ethnicity. Beyond 'Ethnic groups and boundaries' (Vermeulen and Govers 1994). Amongst the many post 1969 contributions to the development of theories on 'ethnicity', 'identity', 'plural society', 'hybridity', etc., I would like to mention Bentley (1987), Tonkin and others (1989), Cohen (1994), Harrison (1999a, 1999b), Jenkins (1997), Nash (1989), Verdery (1994) and Werbner and Modood (1997). In varying ways these commentators address the fluid character of everyday ethnicity and, in contrast, the exacerbating manipulations of governments and other political interests in order to incorporate populations under ethnic banners. Taking these contributions into consideration it might look futile to return to the original interactional paradigm of Barth (1966, 1969). However, it is assumed that a longitudinal approach might serve to disclose some important aspects of the fluctuating interrelationship between the horizontal onthe-ground relations and the vertical class and government engendered frameworks encapsulating them. And while most of these more recent contributions emphasise fuzzy boundaries, hybridity and situational variations of ethnic ascription as an aspect of (post-)modernity, my contention is that such down-playing of ethnic boundaries seems to have a long history, when cohabitation tended to subordinate ethnicity to other and more influential circumstances related to ecologically determined opportunities and to the dominance of a class hierarchy. In this context it also seems relevant to point to Ingold's (2000) criticism of 'the genealogical model' as the prime paradigm for the taxonomic division of peoples. Barth's line of argument in his 'Introduction' to Ethnic groups and boundaries was based on his transactional approach presented in Models of social organization from 1966. In Models, social interaction amongst actors seeking to achieve certain valued ends through various forms of exchange with others was considered the driving force 
behind patterns of behaviour and regularities in society. Through such interaction values come to be compared and shared systems of evaluation would emerge that engender further transactions and thereby confirm expectations and create 'society', which is basically to be conceptualised as systems in the making, integrating value discrepancies and bridging gaps between separate conversion processes. The Models perspective was based clearly on an economic paradigm, not only through its emphasis on the actor's pursuit of maximisation (or rather optimalisation) of values and interests, but also by its inspiration from entrepreneurial studies of activities that break through conversion barriers between separate value systems and through such innovative work produce new types of profit (Barth 1963). In this way, it was argued, innovative action types become conventions and differences are made commensurable and, in the end, integrated within a shared value system. This integration is the outcome of a feedback between transactional purpose, derived from values and interests, and the results of transactions, in the form of confirmed or new experience: '[...] the analysis of the cumulative effects of transactions has enabled us to isolate a feed-back process, whereby values, though initial to each item of behaviour, become modified and changed through their results.' (Barth 1966: 21).

In Ethnic groups and boundaries, however, this perspective seems to be abandoned in favour of the seemingly opposite idea that differences are confirmed through interaction. In Barth's words:

Entailed in ethnic boundary maintenance are also situations of social contact between persons of different cultures: ethnic groups only persist as significant units if they imply marked difference in behaviour, i.e. persisting cultural differences. Yet where persons of different culture interact, one would expect these differences to be reduced, since interaction both requires and generates a congruence of codes and values - in other words, a similarity or community of culture (cf. Barth 1966, for my argumentation on this point). Thus the persistence of ethnic groups in contact implies not only criteria and signals for identification, but also a structuring of interaction which allows for the persistence of cultural differences (Barth 1969: 1516).

What seems to inspire the argument here is the structuralist paradigm of cognitive ordering of meaning through the comparison of opposites, compare LéviStrauss, and also Bateson's famous 'difference that makes the difference' (1979: 79) phrase. Ethnic identity is revolving around the ethnic boundary that confirms, and is at the same time confirmed by, the contrasting identities interacting with each other in some (restricted) way. It is 'the other' who tells me who I am, ethnically speaking. Our mutually-conceived differences confine the field on which we can interact, exchange messages and objects of value, and since our differences are constantly confirmed, the encouragement to enlarge our field of interaction is restricted. Although individual members of an ethnic category may manage to change social identity, that is to pass through the boundary, this may take more than one generation and demand a skilful adaptation to the cultural competences of the other, as well as the other's adjustment of identity ascription to include such 'immigrants' within the scope of variation contained in the conventional identification of one's own category.

How can this seemingly contradictory notion of the significance of interaction for the breaking down of social diversities and the confirmation of ethnic boundaries be explained? Or, in simpler words, when are ethnic boundaries sharpened, and when are they blurred? Should we retain the argument of the instrumentalist school, that ethnicity is to be understood as the conscious manipulation of certain social identities for the purpose of political gain, the mobilisation of collective interest through the confrontation with 'the other' by constructing him/her as 'the enemy, 'the competitor', or, at least, by ascribing certain significant differences to some parts of one's social environment in order to reduce interaction? Originally put forward by Cohen $(1969,1974)$, this reduction of the concept of ethnicity to the realm of 'informal politics' as he put it, has proved to have a strong descriptive significance. It is constantly confirmed in cases of ethnic conflict, when seemingly harmonious social relations are turned into confrontation and conflict (see for instance Bringa 1995) However, such antagonistic and confrontational mobilisations of support have to appeal to symbols and values to which some basic difference between the groups in question can be attributed in the first place, be it religion (as it very often is) or a history of grievances inflicted upon 'us' by 'the other'. A contended provocation on an individual level may then serve to ignite a conflict between collectives, although the social boundary between them has little significance for practical purposes. In other words, ethnicity is not just instrumental, that is invented for a specific purpose; it needs some primordial quality in order to be made operational. Partners in interaction need some key symbols to function as devices for their mutual identification of each other. However, to explain the integrative functions of social interaction across an ethnic boundary we should imagine this boundary to be of a character that allows interaction to be expanded to other sectors, that is to cover varying aspects of local social life in such a way that persons engaging in interactions come to experience each other's individuality and not just his/her appearance as a representative of the categorical 'other'.

\section{Boundary persistence through a thousand years}

In this context it might be of interest to have a look at what characterised the relationship between Saami and Norwegians in the coastal zone of this diversified population before the introduction of the assimilation project (Hansen and Olsen 2004). Considering the fact that Saami and Norwegians have existed as two distinct 
ethnic categories over more than a thousand years, and accepting the notion that ethnic boundaries persist as an effect of limited interaction across the boundary, one may ask what made them restrict their interaction to limited fields of mutual interchange. To quote Barth again:

Stable inter-ethnic relations presuppose such a structuring of interaction: a set of prescriptions governing situations of contact, and allowing for articulation in some sectors or domains of activity, and a set of proscriptions on social situations preventing inter-ethnic interaction in other sectors, and thus insulating parts of the cultures from confrontation and modification (Barth 1969:16).

One may characterise the time of the original SaamiNorse encounter as a time when their significant 'other' must have been people speaking an incomprehensible language and probably utilising at least some other ecological niches. We may imagine it as the archetypal encounter of immigrant agriculturalists and fishermen with the indigenous hunters and gatherers. The encounter generated various forms of contact and exchange, like furs against agricultural products and metals. The ethnic boundary was indisputably corresponding to contrasting ecological niches. Much later (that is in the latter part of the middle ages), while farming, cattle breeding and local and seasonal fishing continued to sustain the Norwegian population, the Saami population diversified into coastal, permanently settled communities depending on the same niches as their Norwegian neighbours, while other parts of the Saami population specialised in reindeer pastoralism. An ecological and economic gap between the combined fishing and agriculture on the coast and herding in the interior divided not only the Saami internally, but created a category of Saami and Norwegians on the coast with hardly any distinctions when we look at the ecological niches they exploited. In the middle ages the Norwegians were strongly attracted by the fish resources and settled on the outer coast, as close to the fishing grounds as possible, depending on fish not only for subsistence, but more importantly as a commodity that permitted the exchange for grain imported from the south. Later on, in the 17th century, these resources dwindled and the coastal settlers had to move away from their settlements exposed to the open sea and entered the fjords, starting cattle breeding in combination with fjord fishing. In other words, they had to adopt ways of living and niche exploitation that in many ways resembled that of the Saami. The closer contact also resulted in intermarriage and cultural borrowing of various kinds, and even the 'exchange' of languages, in the sense that in many communities on the coast of Troms and Finnmark individuals are reported to have been bilingual in the 19th century (Thuen 1989). In some communities foreign population elements were absorbed into the host community through marriage, in others they formed a separate cluster of people kept apart by the ethnic boundary. We should also keep in mind that the bilateral kinship characterising the Norwegian as well as the Saami community (Pehrson 1964; Thuen 1989) did not prescribe a specific ethnic belonging based on descent, when ancestors were of both categories. The system of consanguinity gave 'mixed' individuals the opportunity to choose either belonging, Saami or Norwegian, and it was the cultural habitus dominating in the community, as well as the demographic composition of it, that decided to which category the individual person should belong. Ethnicity is in the blood, people believed, but whose blood, in a system of consanguinity?

\section{Fields of mutuality}

In broad historical perspective we may discern some basic fields of mutuality in the life worlds of coastal northerners that explain the relatively minor impact of ethnicity in differentiating people's opportunities. The most significant is the ecological one, offering the yields of marine and terrestrial resources, fishing and farming, and the structural one of tenancy, the renting of farmland from a landlord. The system of land tenure lasted until the end of the 19th century. To this concurrence of basic life opportunities we also should add the shared system of religious belief, Laestadianism. This is a conservative or even 'fundamentalist' Lutheran lay movement that emerged around the middle of the 19th century in northern Sweden and spread to large parts of northern Norway and Finland. It gathers Saami and Kvens, and also to a certain extent Norwegians, within the same congregations, sharing a spiritual fellowship across state borders (but with certain divergences in doctrine that does not correlate with ethnic differences). It puts a strong emphasis on the renunciation of worldly goods and the need to publicly confess sins and ask for forgiveness from fellow members. It has generally a critical attitude to the state Church (Norway, Sweden and Finland are constitutionally Protestant Lutheran states), but has refrained from breaking its bond to it. And finally, as mentioned, their mutual integration was (and still is) supported by a kinship system that makes no distinction of the patriline from the matriline or the consanguine from the affinal. There may have been certain preferences of intra- over inter-ethnic marriage, but finding one's spouse from a different ethnic category was far from prohibited. This made for extensive networks of relatives and enhanced the opportunity of finding suitable partners for various kinds of short term transactions or lasting companionships, and it also produced an increasing number of persons who could claim a mixed parentage. In short, the ethnic boundary could indeed be 'temporarily set aside' without much ado whenever some task invited cooperation. By the middle of the 19th century, before the onset of the assimilation policy rendered effectual most directly through the school system, inhabitants in many coastal communities were recorded as bilingual or even trilingual (Saami, Norwegian, Kven) (Thuen 1995: 146147). 
The structural dimension that most profoundly divided the population in the north and defined their life chances to be basically divergent was that of class. Saami, Kven and Norwegian fishers/farmers all occupied a basic set of statuses defined by the niche adaptations they shared, fishing and farming, and by their class position as tenant farmers. The landlord, the merchant, the school teacher, and the priest, were all Norwegians. They were few in number, they were mostly immigrants, but more importantly, they possessed an authority as high level representatives of hierarchical power systems with centres outside the region, the state, the market and the church. The other significantly different category with which people on the coast contrasted was the reindeerbreeding nomads of the interior, Saami like most of them and speaking the same language, but otherwise sharing fewer common traits than the coastal fishers and farmers shared with each other across local ethnic boundaries.

We then may look for an explanation of the apparent paradox that social interaction may have integrating as well as disintegrating impacts in the variable that defines ethnicity as a cultural phenomenon in the first place. We need to ask what people consider to be the distinctive conceptual qualities that separate one category from the other. And whenever such qualities are defined, we have to ask what sustains their differential distribution. In the case of coastal northern Norway these sustaining forces seem to reside mainly outside the local community. The prerequisite for locally integrative interaction resided in the shared repertoire of statuses, and the outcome of such processes was a common habitus inculcated as predispositions for actions, beliefs as world view, ecological knowledge, standards of performance, and opportunities and restrictions on the attainment of shared values.

In summing up this brief overview of the historical context we may state that in an environment of shared ecological adaptations as fishers and farmers, and in a shared structural position as tenants depending for their farmland on a landowning élite and for their fishing equipment on a small number of rich merchants (often the same as the landowners), ethnicity did not count as any differentiating variable that would interfere with their class position. Saami and Norwegians were treated alike. The languages may have served to distinguish them, but a mutual bilingual competence may have served to counter the differentiating effect of language. In the latter half of the 19th century Laestadianism grew to become an interethnic meeting place in many parts of the coastal social landscape (Bjørklund 1985; Thuen 1995).

\section{Reinventing the Saami-Norwegian dichotomy}

In a historical perspective this situation of contrastmaking boundaries versus hybridised compositions of identity should be understood in the light of a transition taking place within, first and foremost, the state- orchestrated policy of assimilation lasting more than hundred years (approximately 1850-1960) mentioned above. The assimilation policy drove a wedge into the local system of a seemingly symmetric field of social interaction (Minde 2003; Thuen 2009) by transforming the inter-ethnic relationship from a symmetric to an asymmetric one. The outcome was a ranking of ethnic categories in which a sense of social equality created by common fate had reigned, through implanting the notion of an evolutionary engendered cultural superiority of all things Norwegian in the minds of Saami as well as Norwegians. We may consider it a transition from a commonality reminiscent of Durkheim's (1933) mechanical solidarity to one of organic solidarity allowing for an ethnically differentiated society exhibiting asymmetric relationships and a systematic diversification of career opportunities in economic and political systems on the local and regional levels.

The policy of assimilation did not succeed although the state tried for more than hundred years. Or, more correctly, it succeeded in some areas, it believed it succeeded in some other areas, and it obviously did not succeed in some third areas. And, as we shall see, it imposed an ethnic awareness where it intended to wipe it out. In its effort to homogenise the population the state not only severed bonds of equality (class and ethnicity), it actually created a generational barrier between grandparents and grandchildren, and it is exactly this barrier that so many younger persons since the 1960s have sought to transgress by engaging in an effort to (re)gain a Saami identity, for example by learning the Saami language to be able to speak with their grandparents in the language that was once theirs but which they did not transfer to their children (Hovland 1996, Minde 2003, Thuen 1995).

There is one aspect of the state's assimilation project that should not go unmentioned in this context. That is the contradictory message it left when, on one hand, the authorities, and in particular the educational authorities down to the local teacher, argued that learning Norwegian and forgetting the Saami language was the only way for the Saami to be emancipated from poverty and discrimination, and on the other hand their Norwegian neighbours constantly told them, directly or indirectly, that they would never be able to rub off all signs of Saami identity. They would still speak a 'broken Norwegian', and anyway, the knowledge of who their ancestors were would not be forgotten. The self-image that this situation created was, for many, characterised by a sense of stigma (Eidheim 1971). The contradictory message produced an inescapable double-bind: efforts to absorb a Norwegian cultural competence were encouraged from outside, that is by the school, while at the same time performances of such competence were ridiculed and rejected by their close Norwegian counterparts. When people were led to believe that Saaminess indicated an inferior, more 'primitive' culture and a corresponding inferior identity, Norwegians might also feel their own identity jeopard- 
ised through Saami assimilation and adopted the concept of it being some sort of identity pollution (Harrison 1999a; 1999b). Only slowly has this stamp of inferiority disappeared from local discourse, to be supplanted with either an acceptance of Saami identity as complementary to Norwegian, or by a consensus, in the form of a silent agreement, that the ethnic boundary has disappeared and everyone is now a 'Northerner'.

This is where one finds today a conspicuous diversity in the self-understanding and presentation of identity. Some communities display an acceptance of ethnic plurality and a revitalisation of Saami and Kven idiomatic expressions, while others adhere to a local consensus of disregarding diversity and confirming the 'Northerner' identity as their basic, shared identity. This also implies that in some communities and families awareness of ethnic descent is kept alive, whereas in others it is suppressed or even forgotten, that is considered of no relevance for their self-understanding (Olsen 2008). However, there is always the chance that a specific public event, certain political issues or the personal choice of a family member to declare his/her self-identification as a Saami will spur a debate around the relevance of the ethnic boundary.

The second phase in the rise of ethnic awareness is that of Saami (and, somewhat later, Kven) ethnopolitical emancipation taking place within a rather narrow span of time, from the late 1960s until the present. We are actually talking of little more than one generation's experience, since the emerging collective self-awareness of Saamihood triggered by the Alta conflict ${ }^{3}$ and the idea of a not just contrasting, but complementary Saami collective identity, a nationhood, subsequently to be accepted and confirmed by the Norwegian government as a correction to the formerly dominant and precious idea of national homogeneity. The emerging Saami nationhood, however, had to construct its emblems from a cluster of cultural idioms mainly to be found in just one area, that of the reindeer-herding people of inner Finnmark and some few exclaves to the south. They are far from representative, numerically speaking, of the whole Saami community. So how could the predominantly Norwegianspeaking, not reindeer-breeding 'potential' coastal Saami be persuaded that they were Saami after all, and how were they to persuade others, the reindeer herders and the Saami speakers as well as their Norwegian neighbours, of their Saami identity?

\section{Dilemmas and challenges in forging a shared Saami identity}

The dilemma concerns the issue of cultural diversity within the ethnic boundary, when we consider an ethnic minority that has no state border to define its nationhood formally. Norway's borders were undisputed all through the process of national emancipation in the 19th century. This meant that despite regional and class differences, and despite deep political controversies (even about what should be deemed nationally appropriate, compare the Norwegian language issue of the Danish-inspired bokmål versus the dialect-inspired nynorsk), national identity corresponded with citizenship. And lastly, after a process of class and gender emancipation, this status of Norwegian citizen came to comprise equal political rights on an individual basis. The national border comprised a social, a cultural, and, not least, a regional diversity. It is quite obvious that it also enabled diversity, in the sense that it did not incur a suspicion or accusation of deviance, of being 'less Norwegian' than the rest of the citizens. It did not put anyone's belonging and sense of a shared identity as a member of the imagined nationhood in jeopardy. ${ }^{4}$

This is not so when we consider the Saami. Their nationhood was, and to a large degree still is, a shared belonging in the making. The 'imagined community' notion of nationhood introduced by Anderson (1983) would hardly cover all individuals who, with reference to descent alone, might be entitled to a Saami identity. In the eye of the outside world, that is not just to their regional neighbours, but more importantly to Norwegians in the south and foreign tourists, the authentic Saami still conventionally means reindeer-breeding nomads. It is difficult for the Saami on the coast to overcome this outside regard and substitute it for an internal one that embraces diversities without making them the basis for a ranking scale from 'more' to 'less' Saami. In the process of Saami revitalisation the coastal population of mixed ancestry was left in confusion. The reconstruction of Saami personhood had little sign material to its disposal if it was not to rely on notions of ways of life from before World War II, or, ideally, from before the assimilation process. ${ }^{5}$ Authenticity became a contested issue for the Saami revivalists of the 1960s and 70s (Stordahl 1997), and questions like 'who and where are the Saami' and 'what is Saaminess' were not easily answered (Thuen 2002). As mentioned, one answer to the confusion has been to adopt the identity of 'Northerner', which seems to be a label comprising an ancestry background of a rather mixed character but with a clear adherence to a Norwegian, not a Saami category and very often also rejecting the ethnic identity issue as a matter of little concern, an 'invention' by certain politicians and academics (see for example Kramvig 1999).

Also as has been pointed out, for example by Olsen (2008), it is a fact that for many persons living in areas outside those settlements where the Saami language is used on a daily basis, the presentation of oneself as a Saami is only activated ephemerally, inadvertently, or, as an opposite, emphasised and celebrated at specific occasions. It is not a performance that signals an identity that a person intends to present and expects to be judged by in daily interaction, as this person's normal behaviour. What the ethnopolitical changes and the revitalisation of Saami identity performances have brought about is that these occasions have become more frequent and much more accepted, as we can see at festivals, at inauguration rituals such as weddings and confirmations, exam 
diploma handouts, etc. At such occasions it is no longer exceptional that some participants are wearing a Saami costume. This means that there has been a profound transformation of boundary signification that is most clearly distinguished when we compare the pre-assimilation and the post-assimilation periods with each other. Contrary to Barth's perspective of ethnicity as a rather permanent phenomenon, 'occasional' or 'situational' ethnicity (Okamura 1981) seems to be a more adequate notion of the Saami-Norwegian relationship as found in coastal North Norway.

\section{A Saami modernity?}

The break with a Saami past caused by the assimilation process cannot be healed by the state's recognition of the Saami as an indigenous people, and neither can the Saami ethno-political achievements and their global positioning within the world of indigenous peoples create a kind of peoplehood that approximates a nationhood complementary to their Nordic majority counterparts. The concept of Sápmi as a shared homeland for all Saami is an ideological construction without specified borders, and it is a construction at odds with the premodern notion of Saami society as primarily a local society (Eriksson 2002). There is a basic difference between the 19th century political and cultural élite project of creating a Norwegian imagined community out of the many local and regional diversities that once constituted Norway as a geopolitical entity, and the Saami modern ethno-political enterprise of consolidating a Sápmi above the multitude of diversities of not just a dialectical and economic character, but also an experiential one as represented by a heritage of ethnic disparagement.

We can see this problem exposed in the fact that the ideological construction of Saami indigeneity is also an issue of internal debate, dating back to the reorganisation of Saami ethno-politics in the 1970s when the Saami movement confronted the government with their claims of minority rights, but was criticised from within by those who were more concerned with economic survival of local communities than with challenging the government by demands of ethnic emancipation and recognition of indigenous status. In reality, the Saami idealistic effort to create a distinct Saami modernity, exhibiting a repaired link to the Saami past as well as a modern otherness complementary to the Norwegian mainstream society, seems a futile project. When we look beyond the region where Saami identity is an everyday obviousness, this leaves the articulation of Saaminess to the private sphere and to the occasional public celebrations of identity, like 'the Saami people's day' (Olsen 2008). Such celebrations, however, seem to have gained a level of acceptance by the 'Northerners' with a foot in both ethnic camps, which has superseded the formerly rather aggressive protests against such disruptions of the silent agreement not to make a point any more of the ethnic boundaries that determined people's identities in the past.

Today we see a renewed debate around the legitimacy of ethnically defined land rights triggered by the introduction of the Finnmark Act. Passed by the Norwegian Parliament in 2005, the Finnmark Act recognises the right of the citizens of Finnmark County, predominantly Saami but also Norwegians, to own the land that they have used for their livelihood since time immemorial. The territory in question was formerly owned by the stateThe Finnmark Property is the land-holding unit managing the area handed over to it by the state (about $96 \%$ of the area of the county of Finnmark).

The paradox here seems to be that the act, itself the outcome of a Saami ethno-political pressure on the government to acknowledge its commitment to international declarations of indigenous rights, in particular the International Labour Organisation's Convention 169 and its confirmation of indigenous land rights, does not confer such rights exclusively on the Saami. The privileged status is defined by locality and customary use. The board of the Finnmark Property comprises an equal number of representatives elected by the Saami Parliament and the Finnmark County Council, respectively. In other words, the mixture of ethnicities is confirmed and the boundary defining eligibility to land rights is derived from time (customary use) and space (Finnmark inhabitant, local community membership). In administrative and legal terms boundaries should be indisputable, and status rights clearly defined. In this context ethnicity is a particularly slippery concept. That may be part of the reason why the government ruled (and the Saami Parliament accepted) that the right of ownership is to be conferred to inhabitants of the county, Saami as well as Norwegians. However, opponents of the act, many of them 'Northerners' on the coast, argue that it is in reality an exclusive privilege of the Saami since they dominated the interior of the county and have established the required right based on customary use. Ethnicity is again politicised as it is being suspected of bestowing an exclusive right upon just one of the two categories (or three, if the Kvens are reckoned) in the region.

The fluidity of ethnic membership today might perhaps be seen in some respects as reflecting a continuance of the flexibility of social organisation that prevailed in traditional society. It is inviting a Saami modernity that is not complementary to but encapsulated by the Norwegian (or rather global) one and insisting on defining its boundaries as fluid and permeable. But at the same time and as an opposite force, Saami ethnicity is also confirming its boundary as complementary and contrasting, depending on situation and purpose and founded on a multi-cultural competence.

\section{Conclusions}

Ethnic ascription is normally based on locally shared knowledge of a person's ancestry and on assessments 
of that person's cultural skills, way of life and specific competences incorporated through a process of socialisation. The mixed ancestry of Norwegian, Saami, Kven and other categories found in many parts of northern Norway is a kind of common denominator. Inter-marriage has occurred to a varying extent in time and place. There was hardly a collective prohibition of inter-ethnic marital relations, although intra-ethnic preferences may have prevailed depending on the demographic composition of communities. Affinal links across the ethnic boundary seem to have occurred more or less frequently at all times, and the bilateral kinship ideology immanent in the Norwegian as well as the Saami society could hardly prescribe a specific ethnic belonging based on descent, when ancestors were of both categories. Depending on demographic as well as political circumstances, the system of consanguinity gave 'mixed' individuals the opportunity to choose between Saami and Norwegian belonging, or to de-emphasise the relevance of ethnicity in their identity construction. But this means that we also need to consider under what circumstances, and for what purposes, the issue of ethnic categorisation is made relevant in interaction. In most everyday social encounters today, this knowledge seems to be of little relevance and interactions are based primarily on the mutual assets, qualities, skills and reputations characterising the social person as an individual.

The other variable of determining ethnic belonging is what is being observed, publicly, as a person's behavioural skills, his or her cultural competence. Again we may state that there was and still is very little raw material that may be employed for construction of symbolic demarcation of ethnic identities on the coastal scene. There is reason to argue, then, that what once had served as an ethnic demarcation line during the first centuries of ethnic encounter was a sum of language difference, ecological niche contrast, religious belief and cosmology. In the coastal zone this line dwindled to some extent as economic forces drew the parties together and encapsulated them in a shared habitus of a peasantry under the regime of land tenure and increasing governmental and church dominance. This process prepared the ground for an extensive transactional system of commodities, of marriage partners, and of shared, embodied experience within a habitus that for many purposes was one and the same for both categories. Following Barth's perspective on the integration of culture in Models, this process must have engendered an extension of interactional fields and thus generated a shared value system, in contrast to the former ethnically produced confirmation of difference that channelled interaction to few and predetermined fields and encouraged avoidance of contact on others.

The reason why the two ethnically distinct categories did not merge within this shared common habitus during the centuries of close contact before the period of governmental assimilation policy must be attributed to some counteracting forces residing in a diver- ging heritage of culture and meaning, and embodied in language, concepts, rituals and beliefs that linked the coastal Saami to their reindeer breeding relatives in the interior rather than to their Norwegian neighbours. This alternative relationship was kept intact and must have been conceptualised as significant, relevant, and important for certain purposes. This preserved the coast as bicultural rather than increasingly monocultural, despite a more or less extensive inter-ethnic contact surface.

What the governmental assimilation project achieved was to discredit this bi-culturality and inflict upon it a notion of asymmetry, of Saami inferiority and Norwegian superiority. By so doing, and while it removed the major ethnic diacritica from the Saami population (in particular the language), it exacerbated the ethnic distinction rather than softened it by insisting that Saami were an inferior race to Norwegians. It is on this general background that we should understand the dilemmas of ethnic reconstruction amongst the coastal Saami within a social context that to a large extent has come to a silent agreement of avoiding the subject of ethnicity. This is confirmed by the fact that there is no basic distinguishing mark that is shared by all those who reckon themselves to be 'Saami' but not by any 'Norwegian'. Disagreements abound on who is and who is not a 'Saami', so why not rather subscribe to a self-definition as 'Northerner'? It is precisely when the silent agreement is broken for some specific purpose or by some event or issue external to the local community, that slumbering ethnic identifications may come to the fore (Bjerkli and Thuen 1999; Thuen 2003).

Notes
1. The Saami are the indigenous people of northern
Fennoscandia (Norway, Sweden and Finland) and
the Kola Peninsula. Their origin dates back several
hundred years B.C. 'Kven' is the ethnonym of people
descending from Finnish speaking immigrants during
the eighteenth century and after, but small groups of
Kvens may have lived in the interior of north Norway
as early as the sixteenth century. As this article should
make clear, population numbers cannot be specified
exactly. The Saami are estimated at between 70.000
and 100.000 in Norway and the Kvens at between
10.000 and 15.000 .

2. 'Indigeneity' is used here as a relational term, indicating the shared fate of an ethnic minority of being the object of colonisation and subsequent post-colonial encapsulation within a state system dominated by a majority descended from the original colonisers. In north Norway there is no specific dating of a Norse or Germanic conquest.

3. The Alta conflict erupted when the government in the late 1970 s decided to dam a river intersecting important reindeer pastures for the purpose of hydro-electric production. Through hunger strikes and road blockades Saami activists and environmentalists managed to rally strong national and international support, but were finally forced to give up the battle. In a sense they won the war, however, when the government sat down 
to investigate the Saami claim of aboriginality and finally agreed to establish a Saami elected parliament and recognise the Saami as an indigenous people by way of constitutional amendment.

4. Immigrants and their descendants have, of course, over the last 20-30 years set this notion of shared nationhood under pressure. But the issue is still more of a public experience in the south of Norway than it is in the north.

5. Towards the end of World War II the retreating German army destroyed all material property in the counties of Finnmark and northern Troms through a scorched earth strategy. The past as material culture was thus separated from the present and obliterated.

\section{References}

Anderson, B. 1983. Imagined communities. Reflections on the origin and spread of nationalism. Thetford: Verso.

Barth, F. 1966. Models of social organization. London: Royal Anthropological Institute (occasional paper 23).

Barth, F. 1969. Introduction. In: Barth, F. (editor). Ethnic groups and boundaries. The social organization of culture difference. Oslo, London: Oslo University Press, Allen and Unwin.

Barth, F. 1994. Enduring and emerging issues in the analysis of ethnicity. In: Vermeulen, H., and C. Govers (editors). The anthropology of ethnicity. Beyond 'Ethnic groups and boundaries'. Amsterdam: Het Spinhuis: 11-32.

Barth, F. (editor). 1963. The role of the entrepreneur in social change in northern Norway. Oslo: Universitetsforlaget.

Bateson, G. 1979. Mind and nature: a necessary unity. London: Wildwood House (Advances in systems theory, complexity, and the human sciences).

Bentley, G.C. 1987. Ethnicity and practice. Comparative Studies in Society and History 29: 24-55.

Bjerkli, B., and T. Thuen. 1999. Lokalt eller nasjonalt? Divergerende diskurser om legitimering av rettigheter. [Local or national? Divergent discourses on the legitimization of rights] Norsk antropologisk tidsskrift 10(3-4): 179-192.

Bjørklund, I. 1985. Fjordfolket $\mathrm{i}$ Kvænangen [The fjordal residents of Kvaenangen, north Norway]. Oslo: Universitetsforlaget.

Bringa, T. 1995. Being Muslim the Bosnian way: identity and community in a central Bosnian village. Princeton: Princeton University Press.

Cohen, Abner 1969. Custom and politics in urban Africa. London: Routledge and Kegan Paul.

Cohen, Abner 1974. Two-dimensional man. An essay on the anthropology of power and symbolism in complex society. Berkeley: University of California Press.

Cohen, Anthony 1994. Self consciousness. An alternative anthropology of identity. London: Routledge.

Durkheim, E. 1933 [1893]. The division of labor in society. Glencoe, III.: Free Press.

Eidheim, H. 1971. When ethnic identity is a social stigma. In: Eidheim, H. Aspects of the Lappish minority situation. Oslo: Universitetsforlaget.

Eriksson, J. 2002. The construction of Sápmi: towards a transnational polity? In: Karppi, K., and J. Eriksson (editors). Conflict and cooperation in the north. Umeå: Norrlands Universitetsförlag.

Gaski, L. 2008. Sami identity as a discursive formation: essentialism and ambivalence. In: Gaski, H., S. Jentoft, and G. Midré (editors). Indigenous peoples: self-determination, knowledge, indigeneity. Delft: Eburon Academic Publishers.

Hansen, L.I., and B. Olsen. 2004. Samenes historie fram til 1750 [Saami history until 1750]. Oslo: Cappelen Akademisk Forlag.
Harrison, S. 1999a. Cultural boundaries. Anthropology Today 15(5): 10-13.

Harrison, S. 1999b. Identity as a scarce resource. Social Anthropology 7(3): 239-251.

Hovland, A. 1996. Moderne urfolk. Samisk ungdom i bevegelse [Modern aboriginals. Saami youth in motion]. Oslo: UNGforsk/NOVA, Cappelen Akademisk Forlag.

Ingold, T. 2000. Ancestry, generation, substance, memory, land. In: Ingold, T. The perception of the environment. Essays in livelihood, dwelling and skill. London, New York: Routledge.

Jenkins, R. 1997. Rethinking ethnicity. Arguments and explorations. London: Sage Publications.

Kramvig, B. 1999. I kategorienes vold [Categorical violence]. In: Eidheim, H. (editor). Samer og nordmenn. Temaer i jus, historie og sosialantropologi [Saami and Norwegians. Themes in law, history and social anthropology]. Oslo: Cappelen Akademisk Forlag.

Kramvig, B. 2005. The silent language of ethnicity. European Journal of Cultural Studies 8(1): 45-64.

Minde, H. 2003. Assimilation of the Sami - implementation and consequences. Acta Borealia 20(2): 121-146.

Nash, M. 1989. The cauldron of ethnicity in the modern world. Chicago, London: The University of Chicago Press.

Okamura, J.Y. 1981. Situational ethnicity. Ethnic and Racial Studies 4(4): 452-465.

Olsen, K. 2008. Identities, ethnicities and borderzones: examplars from Finnmark, northern Norway. Unpublished $\mathrm{PhD}$ Dissertation. Bergen: University of Bergen.

Paine, R. 1974. Second thoughts about Barth's models. London: Royal Anthropological Institute (occasional paper).

Paine, R. 2003. Identitetsfloke: Same-same. [Identity puzzle: Saami-Saami]. In: Bjerkli, B. and P. Selle (editors). Samer, makt og democrati. Sametinget og den nye samiske offentligheten, [Saami, power and democracy. The Saami Parliament and the new Saami Public order]. Oslo Gyldendal Akademisk.

Pehrson, R. 1964. The bilateral network of social relations in Könkämä Lapp district. Oslo: Universitetsforlaget.

Scott, J.C. 1998. Seeing like a state. How certain schemes to improve the human condition have failed. New Haven, London: Yale University Press.

Storaas, K. 2007. 'Finland er bak oss, Norge er vårt land'. Konteksters betydning for etniske endringsprosesser $\mathrm{i}$ Sør-Varanger. ['Finland is behind us, Norway is our land.' The significance of contexts for processes of ethnic change in SouthernVaranger]. Unpublished PhD dissertation.Tromsø: University of Tromsø.

Stordahl, V. 1997. Same i den moderne verden. Endring og kontinuitet $i$ et samisk lokalsamfunn [Saami in the modern world. Change and continuity in a Saami local community]. Karasjok: Davvi Girji O.S.

Thuen, T. 1989 'Mixed' descent and ethnogenesis - some comparative considerations of contact situations in the north. Acta Borealia 6(1): 52-71.

Thuen, T. 1995. Quest for equity. Norway and the Saami challenge. St. John's, Nfld.: ISER Books.

Thuen, T. 2002. In search of space: challenges in Saami ethnopolitics in Norway 1979-2000. In Karppi, K., and J. Eriksson (editors). Conflict and cooperation in the north. Umeå: Norrlands Universitetsförlag.

Thuen., T. 2003 Lokale diskurser om det samiske [Local discourses on Saamihood]. In Bjerkli, B., and P. Selle (editors). Samer, makt og demokrati. Sametinget og den nye samiske offentligheten [Saami, power and democracy. The Saami 
Parliament and the new Saami public order]. Oslo: Gyldendal Akademisk.

Thuen, T. 2007. Noen problemstillinger i studiet av etnisitet $i$ samhandlingskontekster [Some problems in the study of ethnicity in interactional contexts]. In: Lindgren, A.R., E. Niemi, M.A. Hauan, L. Niiranen, and T. Thuen (editors). Kvener og skogfinner i fortid og nåtid [Kvens and Saami in the past and the present]. Tromsø: Speculum Boreale.

Thuen, T. 2009. La gestion interne de la diversité. La relation de l'État avec les Sames et les Norvégiens. Ethnologie française 39(2): 265-274.
Tonkin, E., M. MacDonald, and M. Chapman (editors). 1989. History and ethnicity. London: Routledge (ASA Monograph 17).

Verdery, K. 1994. Ethnicity, nationalism and state making. 'Ethnic groups and boundaries': past and future. In: Vermeulen, $\mathrm{H}$., and C. Govers (editors). The anthropology of ethnicity. Beyond 'Ethnic groups and boundaries'. Amsterdam: Het Spinhuis: 33-57.

Werbner, P., and T. Modood (editors). 1997. Debating cultural hybridity. Multi-cultural identities and the politics of anti-racism. London and New Jersey: Zed Books.

\title{
Notions of property: traditional land use and boundaries in the Deh Cho region
}

\section{Carol J. Brown-Leonardi}

The Centre for Citizenship, Identity and Governance (CCIG), Open University, Milton Keynes MK7 6BJ and The Centre for Interdisciplinary Studies in the Humanities (CISH), University of Essex, Wivenhoe Park, Colchester C04 3SQ (cjm@ camits.co.uk)

\begin{abstract}
The Deh Cho Dene have been negotiating territorial land since early European settlement. This paper argues that the changing needs of Deh Cho Dene society has changed their concept of property and this transformation has evolved with a responsibility to conserve cultural practice and ecological balance in Deh Cho Dene territorial lands. The article considers how the changing need of European society addresses property and ownership in the context of basic human rights and consumer interests. It uses the theories of Macpherson, Locke, and Marx to construct a model to understand the property relations that exist in the Deh Cho Dene region. Accordingly, the paper addresses oral narratives to give historical insight into the relations between neighbouring tribal groups and their understanding of territorial boundaries. An account of present day negotiations highlights the various initiatives taken to protect traditional interests and uphold historical claim to the territory. The negotiation of joint ventures and property ownership has evolved with concerns over ecological sustainability and the protection of a subsistence lifestyle, which is critical for the social and economic interests of Deh Cho Dene culture, and is closely connected to the land.
\end{abstract}

\section{Introduction}

There are numerous theories of property that have influenced the understanding of notions of property ownership. This paper will explore some of the cultural concepts that revolve around the possession of property and examine how Canadian land settlement policies assist in shaping local Deh Cho Dene notions of ownership. The Deh Cho Dene are settled in ten communities across the Northwest Territories (NWT) in the circumpolar Canadian north. This area is abundant in nonrenewable resources such as oil, gas and precious minerals and contains the Mackenzie Valley watershed. The Deh Cho Dene are one of the North American indigenous groups that comprise the Athabaskan speaking family of peoples. The population is currently 3500 in an area of $70,000 \mathrm{~km}^{2}$. There are three official languages in the region, the indigenous Slavey, French and English. Slavey is the first official language in the region, which is used alongside English in political meetings and negotiation sessions. Amongst the varied definitions of property that will be presented, is an examination of the concept of the 'claim to use' and how it relates to property ownership. The focus will be on the cultural perceptions that represent 'claim to use' or 'own', such as the historical connection to traditional territories. Oral narratives and ethnographic fieldwork are used to demonstrate the Deh Cho Dene perceptions of land ownership and claims to territory. The land settlement negotiations with the Canadian government on issues of land ownership, sovereignty and jurisdiction will be used to illustrate this point. In short, I argue that Deh Cho Dene values on property have shifted with the development of negotiations for land. Land and negotiation cannot be separated.

Contemporary approaches to property will be examined in an exploration of how Deh Cho Dene concepts of property may have developed in the course of negotiations with the federal government and the 